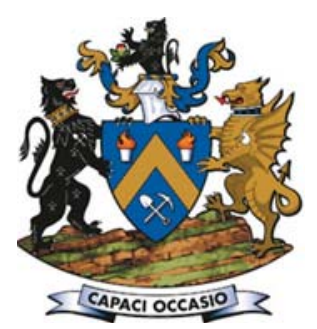

\title{
Experimental study on phosphorus distribution ratio and capacity of environment-friendly dephosphorization slag for high-phosphorus hot metal pretreatment
}

\author{
by F. Yang*, X.G. Bi*, and J.D. Zhou*
}

\section{Synopsis}

In this investigation, the phosphorus distribution ratios in the $\mathrm{CaF}_{2}$ system and $\mathrm{B}_{2} \mathrm{O}_{3}$ system dephosphorization slags for high-phosphorus hot metal pretreatment were measured by an indirect method under laboratory conditions. Firstly, the phosphorus distribution ratio between liquid slag and solid iron was measured, and then the phosphorus distribution ratio between liquid slag and hot metal was calculated. Phosphorus capacity was calculated in terms of the composition and optical basicity of the slag. Dephosphorization slag was also studied by scanning electron microscopy, energy dispersive analysis, and $\mathrm{X}$-ray diffraction analysis. The experimental results show that the phosphorus capacity of the $\mathrm{B}_{2} \mathrm{O}_{3}$ slag system is much greater than that of the $\mathrm{CaF}_{2}$ system. It is demonstrated that $\mathrm{B}_{2} \mathrm{O}_{3}$ can completely replace $\mathrm{CaF}_{2}$ as fluxing agent for high-phosphorus hot metal pretreatment. With $\mathrm{CaF}_{2}$ as fluxing agent, the phosphorus capacity increases with increasing $\mathrm{CaO}$ content in the slag, but the phosphorus distribution ratio decreases. $\mathrm{B}_{2} \mathrm{O}_{3}$, when used as fluxing agent, can react with high melting point phases such as $2 \mathrm{CaO} \cdot \mathrm{SiO}_{2}$ and $3 \mathrm{CaO} \cdot \mathrm{P}_{2} \mathrm{O}_{5}$ in the slag to form new phases with low melting points such as $11 \mathrm{CaO} \cdot \mathrm{B}_{2} \mathrm{O}_{3} \cdot 4 \mathrm{SiO}_{2}, 2 \mathrm{CaO} \cdot \mathrm{B}_{2} \mathrm{O}_{3} \cdot \mathrm{SiO}_{2}$, and $\mathrm{Ca}_{9.93}\left(\mathrm{P}_{5.84} \mathrm{~B}_{0.16} \mathrm{O}_{24}\right)\left(\mathrm{B}_{0.67} \mathrm{O}_{1.79}\right)$, thereby acting as a fluxing agent. When the ratio of $w\left(\mathrm{~B}_{2} \mathrm{O}_{3}\right) / w(\mathrm{CaO})$ is 0.16 , the phosphorus distribution ratio reaches its maximum value, that is, the dephosphorization ability of the slag is at its maximum.

\section{Keywords}

hot metal pretreatment; dephosphorization; phosphorus distribution ratio; phosphorus capacity.

\section{Introduction}

As international iron ore prices continue to rise, the development of China's steel industry is facing a lot of pressure. Against this background, development and utilization of domestic high-phosphorus iron ore resources is particularly important. When highphosphorus iron ore is used in ironmaking, the phosphorus content in the hot metal can reach $0.35 \%$ or more, and the hot metal must be pretreated. For hot metal with $0.08-0.10 \%$ dissolved phosphorus, the traditional hot metal dephosphorization pretreatment technologies are relatively mature. However, when using these methods to dephosphorize hot metal containing $0.35 \% \mathrm{P}$ or more, the amount of dephosphorization slag can reach $100-150 \mathrm{~kg}$ per ton of hot metal. Furthermore, the traditional dephosphorization methods require the addition of large amounts of $\mathrm{CaF}_{2}$ as fluxing agent, and this results in high fluoride levels in the dephosphorization slag. The fluorine in the slag can partially dissolve in water and thereby causes high fluoride concentration in the water and soil. Once the fluoride is absorbed by humans or animals, it can result in toxic effects on the central nervous system and myocardium. In addition, fluoride can accumulate in the environment, and thereby pose a health risk to animals and humans through the food chain (Li, 2007; Liu, Wang, and Dong, 2011, Diao, 2013). The objective of this research is to replace $\mathrm{CaF}_{2}$ with $\mathrm{B}_{2} \mathrm{O}_{3}$ as fluxing agent while achieving the expected goals of hot metal pretreatment.

The melting point of $\mathrm{B}_{2} \mathrm{O}_{3}\left(450^{\circ} \mathrm{C}\right)$ is much lower than that of $\mathrm{CaF}_{2}\left(1419^{\circ} \mathrm{C}\right) \cdot \mathrm{B}_{2} \mathrm{O}_{3} \mathrm{can}$ interact with $\mathrm{FeO}, \mathrm{CaO}, \mathrm{MgO}$, and other oxides to form compounds with low melting points such as $\mathrm{CaO} \cdot \mathrm{B}_{2} \mathrm{O}_{3}$ (m.p. $1154^{\circ} \mathrm{C}$ ). Compared with $\mathrm{CaF}_{2}, \mathrm{~B}_{2} \mathrm{O}_{3}$ has a greater advantage in rapid slagging (Hamano and Horibe, 2004). The purpose of this article is to investigate the influence of environment-friendly dephosphorizing slag composition on the dephosphorization process, and to provide a theoretical basis for the preparation of an environmentfriendly dephosphorization agent that has strong dephosphorization ability. The phosphorus distribution ratio and phosphorus capacity of the $\mathrm{CaF}_{2}$ slag system were also determined.

\section{Experimental method}

The phosphorus distribution ratio and the phosphorus capacity of $\mathrm{B}_{2} \mathrm{O}_{3}$ dephosphorization slag for high-phosphorus hot metal pretreatment were determined under

* Key Laboratory for Ferrous Metallurgy and Resources Utilization of Ministry of Education. Wuhan University of Science and Technology, Wuhan, China.

(c) The Southern African Institute of Mining and Metallurgy, 2016. ISSN 2225-6253. Paper received May 2015; revised paper received Nov. 2015. 


\section{Experimental study on phosphorus distribution}

laboratory conditions using a thermodynamic equilibrium furnace. The interior structure of the furnace is shown in Figure 1. The compositions of the $\mathrm{CaF}_{2}$ and $\mathrm{B}_{2} \mathrm{O}_{3}$ slag systems are shown in Table I and Table II, respectively. The compositions of the pure iron crucible and iron foil are shown in Tables III and IV, respectively. In the experiments, 99.999\% high-purity argon gas was purged to provide an inert furnace atmosphere. Slag samples were thoroughly mixed and placed into pure iron crucibles. The crucibles were then loaded into the furnace, and the furnace was heated to $1400^{\circ} \mathrm{C}$. The temperature was kept constant for 1 hour, and then lowered to $1350^{\circ} \mathrm{C}$, before being kept constant at $1350^{\circ} \mathrm{C}$ for 11 hours. Finally, the crucibles were removed from the furnace and immediately quenched with water to avoid oxidation reactions that would drive the reactions of $\mathrm{Fe}_{2} \mathrm{O}_{3}$ FeO-Fe to equilibrium. The pre-melted slag from the equilibrium experiments was crushed, and placed again in pure iron crucibles, together with pure iron flakes of about 1 $\mathrm{g}$ weight and $0.1 \mathrm{~mm}$ thickness. The crucibles containing the pre-melted slag and iron flakes were then loaded into the furnace, and the temperature was raised to $1300^{\circ} \mathrm{C}$ and kept constant for 12 hours under argon gas protection to obtain a full equilibrium between the slag and iron flakes. Finally, the crucibles were removed and quenched with water to avoid oxidation that would drive the reaction of $\mathrm{P}-\mathrm{P}_{2} \mathrm{O}_{5}$ to equilibrium. The samples obtained from the experiments were treated as follows.

(1) The slag that had adhered on the iron flakes was ground and cleaned up with supersonic waves in an acetone solution

(2) The phosphorus dissolved in the iron flakes was measured with the molybdenum blue light absorption method. The microstructure and elemental composition of the slag were analysed with scanning electron microscopy using energy-dispersive X-ray spectroscopy (SEM-EDS). The minerals in the slag were characterized by X-ray diffraction.

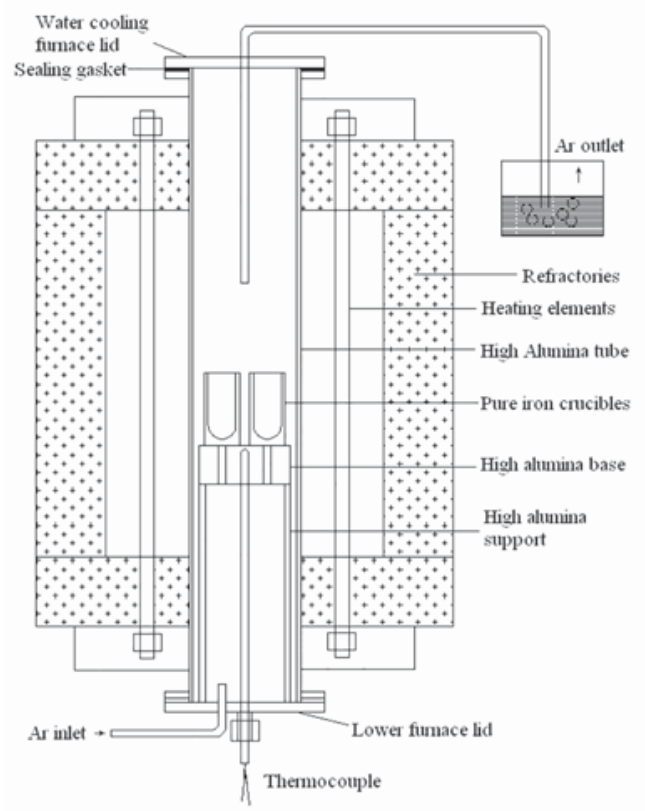

Figure 1-Interior structure of the thermodynamic equilibrium furnace
Calculation of the phosphorus capacity and phosphorus distribution ratio

According to the composition of the slag obtained from the equilibrium experiment, phosphorus capacity is calculated by the following formula (Wei, Yang, and Sommerville, 2002).

$$
\lg C_{\mathrm{PO}_{4}^{3 .}}=\left(-\frac{36412}{T}+37\right) \Lambda+\frac{71493}{T}-30.8
$$

where $\mathrm{C}_{\mathrm{PO}_{4}^{3-}}$ is the phosphorus capacity, $T$ the reaction temperature $(K)$, and $\Lambda$ the optical basicity. The $\Lambda$ is the weighted average of the optical basicity of all components in slag, and is calculated using the formula:

$$
\Lambda=\sum_{B=1}^{n} x_{B} \Lambda_{B}
$$

where $\Lambda_{B}$ is the optical basicity of oxide, and $x_{B}$ is the molar fraction of cations in oxide.

Table I

Composition (mass \%) of $\mathrm{CaF}_{2}$ slag system

\begin{tabular}{|l|c|r|r|r|l|}
\hline No. & FeO & $\mathbf{S i O}_{2}$ & $\mathbf{P}_{2} \mathbf{O}_{5}$ & $\mathbf{C a O}$ & $\mathbf{C a F}_{2}$ \\
\hline $1-0-1$ & 11.32 & 7.06 & 13.44 & 51.73 & 16.45 \\
$1-0-2$ & 10.24 & 9.12 & 16.12 & 48.75 & 15.77 \\
$1-0-3$ & 10.50 & 10.79 & 18.50 & 46.10 & 14.31 \\
$1-0-4$ & 10.37 & 12.03 & 19.65 & 43.72 & 14.23 \\
\hline
\end{tabular}

Table II

Composition (mass \%) of $\mathrm{B}_{2} \mathrm{O}_{3}$ slag system

\begin{tabular}{|l|c|c|c|c|c|c|}
\hline No. & $w\left(\mathbf{B}_{2} \mathbf{O}_{3}\right) / w(\mathrm{CaO})$ & $\mathbf{F e O}$ & $\mathbf{S i O}_{2}$ & $\mathbf{P}_{2} \mathbf{O}_{5}$ & $\mathbf{C a O}$ & $\mathbf{B}_{2} \mathbf{O}_{3}$ \\
\hline 3-0-1 & 0.08 & 8.14 & 9.93 & 15.28 & 61.71 & 4.94 \\
$3-0-2$ & 0.10 & 5.37 & 9.71 & 15.78 & 62.85 & 6.29 \\
$3-0-3$ & 0.12 & 5.85 & 9.81 & 15.43 & 61.53 & 7.38 \\
$3-0-4$ & 0.14 & 6.66 & 7.24 & 15.41 & 62.01 & 8.68 \\
3-0-5 & 0.16 & 6.34 & 7.30 & 14.65 & 61.82 & 9.89 \\
$3-0-6$ & 0.18 & 5.68 & 7.15 & 14.36 & 61.79 & 11.12 \\
\hline
\end{tabular}

Table III

Composition of pure iron crucible (mass \%)

\begin{tabular}{|l|c|c|c|c|c|}
\hline $\mathbf{C}$ & Si & P & Mn & S & N \\
\hline 0.008 & 0.002 & 0.006 & 0.017 & 0.005 & 0.008 \\
\hline
\end{tabular}

Table IV
Composition of iron foil (mass \%)
\begin{tabular}{|l|c|c|c|c|c|c|}
\hline C & Si & Mn & P & S & Cr & Cu \\
\hline 0.07 & 0.0032 & 0.036 & 0.021 & 0.001 & 0.006 & 0.032 \\
\hline Ti & V & As & B & Zn & \multicolumn{2}{|c|}{ Fe } \\
\hline 0.0012 & 0.0001 & 0.005 & 0.001 & 0.011 & \multicolumn{2}{|c|}{99.8} \\
\hline
\end{tabular}




\section{Experimental study on phosphorus distribution}

$x_{B}$ also denotes the molar fraction of oxygen of oxide in the slag, and is calculated by formula:

$$
x_{B}=\frac{n_{\mathrm{O}} x_{B}^{\prime}}{\sum n_{\mathrm{O}} x_{B}^{\prime}}
$$

where $x_{B}^{\prime}$ is molar fraction of oxide, $n_{0}$ is the number of oxygen atoms in the oxide molecule. It is specified that one fluorine atom in the fluoride molecule is equal to $1 / 2$ oxygen atoms. $x_{B}^{\prime}$ can be calculated by:

$$
x_{B}^{\prime}=\frac{w_{B} / M_{B}}{\sum \frac{w_{B}}{M_{B}}}
$$

where $w_{B}$ is the percentage of oxide and $M_{B}$ is the molar mass of oxide.

In this paper, the measured value of the phosphorus distribution ratio is not between liquid slag and carbonsaturated hot metal but between liquid slag and solid iron flake, thus a conversion is needed. Im, Morita, and Sano (1996) calculated the phosphorus distribution ratio between liquid slag and solid pure iron flakes (Tsukihashi, Nakamura, and Orimoto, 1990; Knacke, Kubaschewski, and Heselmann, 1991; Im, Morita, and Sano, 1996; Zhou et al., 2011). The expression of phosphorus distribution ratio is as follows:

$$
L_{\mathrm{P}}^{\mathrm{Fe}-a, \gamma}=\frac{(\% \mathrm{P})}{[\% \mathrm{P}]^{\mathrm{Fe}-a, \gamma}}
$$

where $\alpha L_{\mathrm{P}}^{\mathrm{Fe}-\alpha}$ is the phosphorus distribution ratio between liquid slag and $\alpha$ iron, $L_{\mathrm{p}}^{\mathrm{Fe}-\gamma}$ the phosphorus distribution ratio between liquid slag and $\gamma$ iron, \% $\mathrm{P}$ the mass percentage of $\mathrm{P}$ in liquid slag, $[\% \mathrm{P}]^{\mathrm{Fe}-\alpha}$ the mass percentage of $\mathrm{P}$ in $\alpha$ iron, and $[\% \mathrm{P}]^{\mathrm{Fe}-\gamma}$ is the mass percentage of $\mathrm{P}$ in $\gamma$ iron.

After thermodynamic conversion, the distribution of phosphorus between carbon-saturated iron and $\alpha$ iron and $\gamma$ iron is obtained by:

$$
\frac{[\% \mathrm{P}]^{\mathrm{Fe}-a}}{[\% \mathrm{P}]^{\mathrm{Fe}-\mathrm{C}}}=0.779
$$

([P] in solid iron is larger than $0.41 \%$ )

$$
\frac{[\% \mathrm{P}]^{\mathrm{Fe}-\gamma}}{[\% \mathrm{P}]^{\mathrm{Fe}-\mathrm{C}}}=0.413
$$

([P] in solid iron is smaller than $0.41 \%$ )

where $[\% \mathrm{P}]^{\mathrm{Fe}-\mathrm{C}}$ is the mass percentage of $\mathrm{P}$ in carbonsaturated hot metal.

\section{Results and discussion}

\section{Phosphorus capacity and phosphorus distribution ratio of $\mathrm{CaF}_{2}$ slag system}

Equilibrium compositions and phosphorus capacity calculated for the $\mathrm{CaF}_{2}$ slag system are shown in Table $\mathrm{V}$.

The phosphorus contents in the $\mathrm{CaF}_{2}$ slag system and solid iron flake, and the phosphorus distribution ratio between liquid slag and carbon-saturated hot metal are also shown in Table VI. The relationship between phosphorus distribution ratio and $\mathrm{CaO}$ content is depicted in Figure 2.

It can be clearly seen from Table $\mathrm{V}$ that when the $\mathrm{CaO}$ content in the slag is the highest, the phosphorus capacity of the $\mathrm{CaF}_{2}$ slag system reaches the maximum value. That is, at a CaO content in slag of $49.72 \%$, the phosphorus capacity is $11.66 \times 10^{22}$. At a CaO content in slag of about $44 \%$, the change in phosphorus capacity is small. As can be seen from

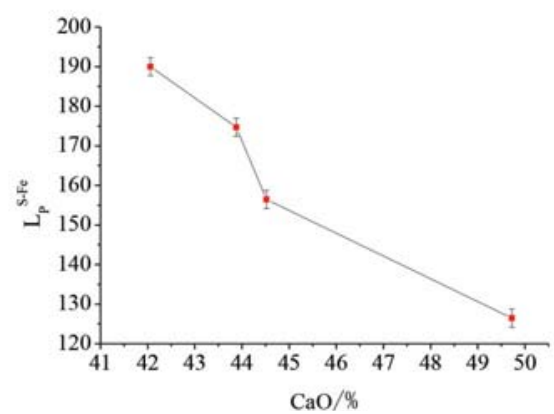

Figure 2-Relationship between phosphorus distribution ratio and $\mathrm{CaO}$ content

Table V

Equilibrium composition (mass \%) and phosphorus capacity of $\mathrm{CaF}_{2}$ slag system

\begin{tabular}{|l|c|c|c|r|r|r|r|}
\hline Test number & $\mathbf{F e O}$ & $\mathrm{Fe}_{2} \mathbf{O}_{3}$ & $\mathbf{C a O}$ & $\mathbf{S i O}_{2}$ & $\mathbf{P}$ & $\mathbf{C a F}_{\mathbf{P O}}{ }^{3-} \mathbf{x} \mathbf{1 0}^{22}$ \\
\hline $1-0-1$ & 7.64 & 3.2 & 49.72 & 6.91 & 5.39 & 16.06 \\
$1-0-2$ & 5.63 & 3.14 & 44.52 & 8.99 & 6.44 & 15.12 \\
$1-0-3$ & 5.78 & 2.3 & 43.88 & 10.51 & 7.19 & 14.60 \\
$1-0-4$ & 6.52 & 2.86 & 42.06 & 11.72 & 8.28 & 13.61 \\
\hline
\end{tabular}

Table VI

Phosphorus distribution ratio of $\mathrm{CaF}_{2}$ slag system

\begin{tabular}{|l|c|c|c|}
\hline Test number & (FeO) (mass \%) & (P) (mass \%) & [P] $_{\mathrm{Fe}}(\mathrm{mass} \%)$ \\
\hline $1-0-1$ & 7.64 & 5.39 & 0.0176 \\
$1-0-2$ & 9.63 & 6.44 & 0.0172 \\
$1-0-3$ & 5.78 & 7.19 & 0.0176 \\
$1-0-4$ & 6.52 & 8.28 & 126.48 \\
\end{tabular}




\section{Experimental study on phosphorus distribution}

Table VI and Figure $2, L_{p}^{\mathrm{s}}{ }^{\mathrm{Fe}}$ increases with decreasing CaO content. For example, as the $\mathrm{CaO}$ content decreases from $49.72 \%$ to $42.06 \%$, the $L_{p}{ }^{\mathrm{s}-\mathrm{Fe}}$ increases from 126.84 to 189.98. $L_{p}{ }^{\mathrm{s}}{ }^{\mathrm{Fe}}$ is influenced synthetically by slag basicity, fluxing agent content (effect of slag melting), and $\mathrm{FeO}$ content, among other factors. $L_{p}{ }^{\mathrm{s}-\mathrm{Fe}}$ of the slag in test 1-0-4 is 189.98 , the maximum value. The basicity of $1-0-4$ slag is 3.76. However, $L_{p}{ }^{\mathrm{s}-\mathrm{Fe}}$ of 1-0-1 slag reaches the minimum value, with a basicity of 17.20 . When the basicity is too high, the dephosphorizing slag contains solid $\mathrm{CaO}$ particles deposited from the bath. The higher the basicity, the more $\mathrm{CaO}$ particles are deposited. Figures 3 and 4 show elemental analyses and a micrograph of $\mathrm{CaO}$ solid particles in melted slags from tests 1-0-2 and 1-0-3, respectively. It can be clearly seen that the quantity and size of $\mathrm{CaO}$ particles in melted slag with $44.52 \% \mathrm{CaO}$ are much greater than in slag with $43.88 \% \mathrm{CaO}$. This explains why $L_{p}^{\mathrm{s} \text {-Fe }}$ bears an inverse relationship to $\mathrm{CaO}$ content. More $\mathrm{CaO}$ particles increase the viscosity of slag, which in turn decreases $L_{p}{ }^{s-F e}$. In this condition, it is required to decrease the basicity of the slag, increase the amount of fluxing agent, or increase the $\mathrm{FeO}$ content of the slag.

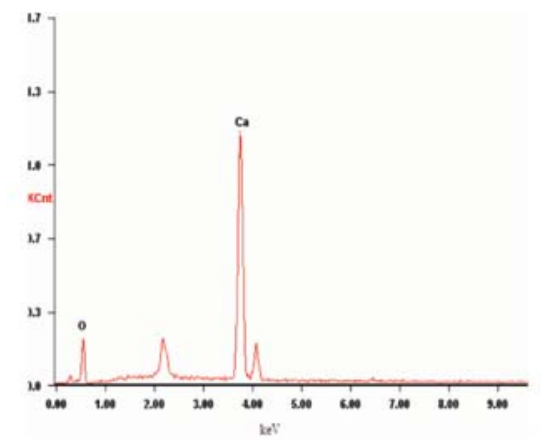

\section{Phosphorus capacity and phosphorus distribution ratio of $\mathrm{B}_{2} \mathrm{O}_{3}$ slag system}

Equilibrium compositions and phosphorus capacity calculated for the $\mathrm{B}_{2} \mathrm{O}_{3}$ slag system are shown in Table VII.

Phosphorus distribution ratios obtained for the $\mathrm{B}_{2} \mathrm{O}_{3}$ slag system between liquid slag and carbon-saturated hot metal are shown in Table VIII. The relationship between phosphorus distribution ratio and $\mathrm{w}\left(\mathrm{B}_{2} \mathrm{O}_{3}\right) / \mathrm{w}(\mathrm{CaO})$ is depicted in Figure 5.

As can be seen from Table VII, the phosphorus capacity of all $\mathrm{B}_{2} \mathrm{O}_{3}$ slag system is generally higher. The highest value is as high as $57.54 \times 10^{23}$. It can be seen from Table VIII and Figure 5 that at a $\mathrm{w}\left(\mathrm{B}_{2} \mathrm{O}_{3}\right)$ to $\mathrm{w}(\mathrm{CaO})$ ratio of 0.16 , the phosphorus distribution ratio reaches the highest value of 156.12. As the $\mathrm{B}_{2} \mathrm{O}_{3}$ content continues to increase, the phosphorus distribution ratio begins to decrease. As such, this kind of slag system (test number 3-0-5) has the highest dephosphorization ability.

When the quantity of $\mathrm{B}_{2} \mathrm{O}_{3}$ is appropriate, during the dephosphorization reaction, $\mathrm{B}_{2} \mathrm{O}_{3}$ reacts with $2 \mathrm{CaO} \cdot \mathrm{SiO}_{2}$ to form $11 \mathrm{CaO} \cdot \mathrm{B}_{2} \mathrm{O}_{3} \cdot 4 \mathrm{SiO}_{2}$ and $2 \mathrm{CaO} \cdot \mathrm{B}_{2} \mathrm{O}_{3} \cdot \mathrm{SiO}_{2}$. Moreover, $\mathrm{B}_{2} \mathrm{O}_{3}$

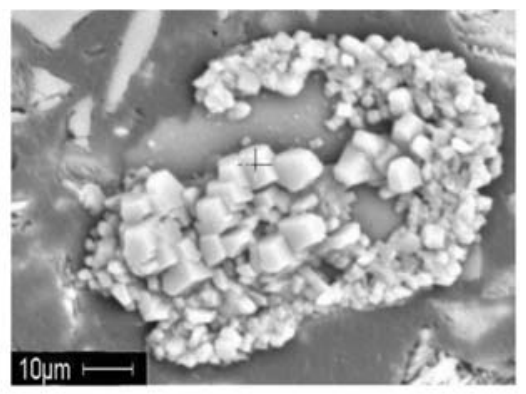

Figure 3-Elemental analysis and micrograph of $\mathrm{CaO}$ particles in slag, test 1-0-2
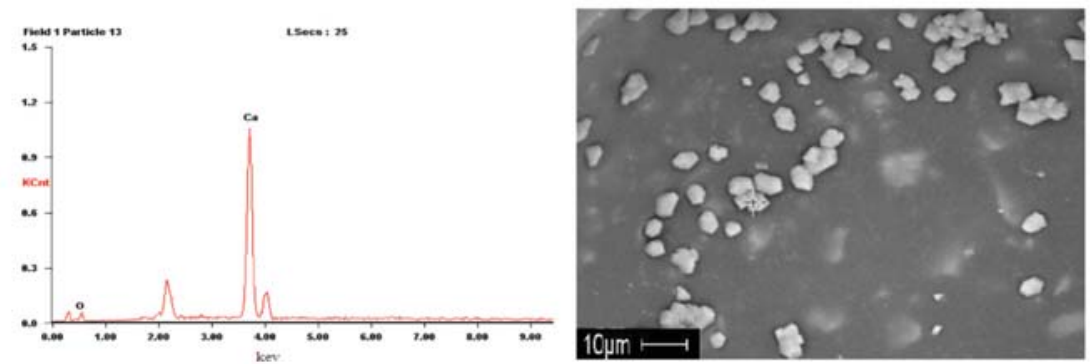

Figure 4-Elemental analysis and micrograph of $\mathrm{CaO}$ particles in slag, test 1-0-3

\begin{tabular}{|c|c|c|c|c|c|c|c|c|}
\hline \multicolumn{9}{|l|}{ Table VII } \\
\hline Equilibriur & nposition (ma & and & norus & ty of $C$ & ag sy & & & \\
\hline Test number & $w\left(\mathrm{~B}_{2} \mathrm{O}_{3}\right) / w(\mathrm{CaO})$ & $\mathrm{FeO}$ & $\mathrm{Fe}_{2} \mathrm{O}_{3}$ & $\mathrm{CaO}$ & $\mathrm{SiO}_{2}$ & $\mathbf{P}$ & $\mathrm{B}_{2} \mathrm{O}_{3}$ & $C_{\mathrm{PO}_{4}^{3-}}^{3-} \times 10^{23}$ \\
\hline $3-0-1$ & 0.08 & 6.55 & 1.58 & 60.91 & 8.23 & 4.83 & 4.87 & 6.46 \\
\hline $3-0-2$ & 0.10 & 4.15 & 1.30 & 60.86 & 5.62 & 5.79 & 6.47 & 57.54 \\
\hline $3-0-3$ & 0.12 & 5.58 & 1.13 & 59.41 & 8.29 & 5.69 & 7.02 & 2.95 \\
\hline $3-0-4$ & 0.14 & 4.54 & 2.76 & 60.81 & 5.53 & 5.63 & 8.12 & 5.62 \\
\hline $3-0-5$ & 0.16 & 5.30 & 1.39 & 59.58 & 8.26 & 6.88 & 9.48 & 1.41 \\
\hline $3-0-6$ & 0.18 & 4.54 & 1.43 & 60.85 & 5.40 & 5.68 & 10.95 & 3.09 \\
\hline
\end{tabular}




\section{Experimental study on phosphorus distribution}

\begin{tabular}{|c|c|c|c|c|}
\hline Test number & $(\mathrm{FeO})$ (mass \%) & (P) (mass \%) & {$[\mathrm{P}]_{\mathrm{Fe}}$ (mass \%) } & $L P^{\mathrm{s}-\mathrm{Fe}}$ \\
\hline $3-0-1$ & 6.55 & 4.83 & 0.0179 & 111.44 \\
\hline $3-0-2$ & 4.15 & 5.79 & 0.0184 & 129.96 \\
\hline 3-0-3 & 5.58 & 5.69 & 0.0173 & 135.83 \\
\hline $3-0-4$ & 4.54 & 5.63 & 0.0183 & 147.06 \\
\hline $3-0-5$ & 5.30 & 6.88 & 0.0182 & 156.12 \\
\hline $3-0-6$ & 4.54 & 5.68 & 0.0183 & 128.19 \\
\hline
\end{tabular}

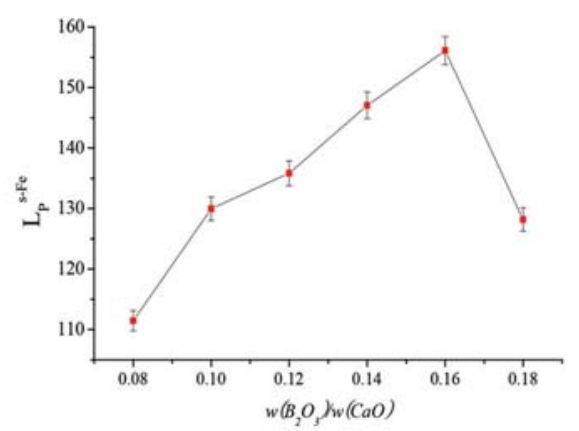

Figure 5-Relationship between phosphorus distribution ratio and $w\left(\mathrm{~B}_{2} \mathrm{O}_{3}\right) / w(\mathrm{CaO})$

continues to react with $3 \mathrm{CaO} \cdot \mathrm{P}_{2} \mathrm{O}_{5}$, which is formed by reaction between $\mathrm{CaO}$ and $\mathrm{P}_{2} \mathrm{O}_{5}$, to form $\mathrm{Ca}_{9.93}\left(\mathrm{P}_{5.84} \mathrm{~B}_{0.16} \mathrm{O}_{24}\right)$ $\left(\mathrm{B}_{0.67} \mathrm{O}_{1.79}\right)$, which has a low melting point. Thus $\mathrm{B}_{2} \mathrm{O}_{3}$ acts as a fluxing agent and is beneficial for dephosphorization reactions. In this case, the phosphorus distribution ratio and capacity are the highest. The XRD pattern from test $3-0-5$ is shown in Figure 6.

\section{Conclusions}

With $\mathrm{CaF}_{2}$ as fluxing agent, the phosphorus capacity of dephosphorization slag for high-phosphorus hot metal is between $2.331 \times 10^{22}$ and $11.66 \times 10^{22}$. Phosphorus capacity increases with increasing slag basicity. However, too high a $\mathrm{CaO}$ content adversely affects the phosphorus distribution ratio because the melting of the dephosphorization slag becomes difficult, and this reduces the fluidity of the slag, hindering diffusion and decreasing the dephosphorization rate.

The phosphorus capacity of the $\mathrm{B}_{2} \mathrm{O}_{3}$ slag system is between $1.41 \times 10^{23}$ and $57.54 \times 10^{23}$, which is one order of magnitude higher than $\mathrm{CaF}_{2}$ system. It has been demonstrated that $\mathrm{B}_{2} \mathrm{O}_{3}$ can completely replace $\mathrm{CaF}_{2}$ as fluxing agent for high-phosphorus hot metal pretreatment.

The phosphorus distribution ratio of the $\mathrm{B}_{2} \mathrm{O}_{3}$ system is 111.44-156.12. At a $w\left(\mathrm{~B}_{2} \mathrm{O}_{3}\right)$ to $w(\mathrm{CaO})$ ratio of 0.16 , the phosphorus distribution ratio reaches its highest value. The dephosphorization ability of this slag system is therefore the strongest.

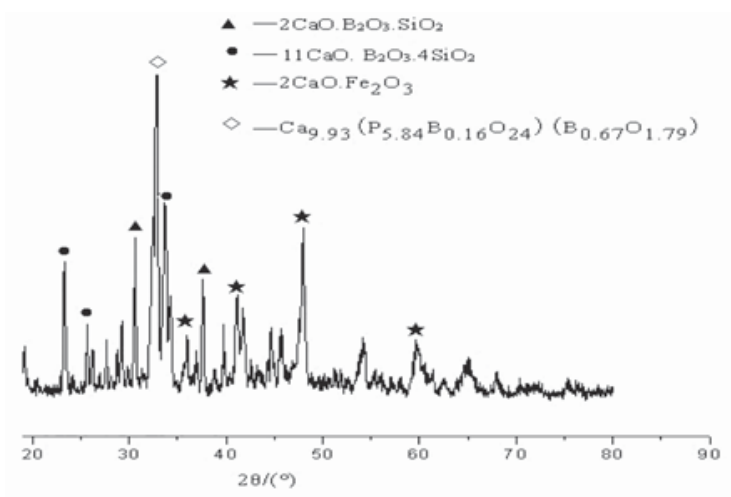

Figure 6-XRD pattern of $w\left(\mathrm{~B}_{2} \mathrm{O}_{3}\right) / w(\mathrm{CaO})=0.164$

\section{References}

DiAo, J. 2013. Effect of $\mathrm{Al}_{2} \mathrm{O}_{3}$ and $\mathrm{Na}_{2} \mathrm{O}$ on dephosphorization of high phosphorus hot metal. Journal of Iron and Steel Research, vol. 25, no. 2. pp. 9-10.

Hamano, T. and Horibe, M. 2004. The dissolution rate of solid lime into molten slag used for hot-metal dephosphorization. ISIJ International, vol. 44, no. 2. pp. 263-267.

IM, J., MoRita, K., and SAno, N. 1996. Phosphorus distribution ratios between $\mathrm{CaO}-\mathrm{SiO}_{2}-\mathrm{Fe}_{\mathrm{t}} \mathrm{O}$ slags and carbon-saturated iron at $1573 \mathrm{~K}$. ISIJ International, vol. 36, no. 5. pp. 517-521.

LI, C. 2007. Fluoride pollution sources, control technology and its source. Iron \& Steel Technology, no. 3. pp. 5-153.

Knacke, O., KubaschewsKi, O., and Heselmann, K. 1991. Thermochemical Properties of Inorganic Substance. Springer-Verlag, Berlin.

Liu, L., WAng, S., and Dong, Y. 2011. Performance of low fluoride dephosphorization slag of hot metal. Journal of Iron and Steel Research International, vol. 18, no. 1. pp. 11-15.

TsuKIHASH, F., NAKAMURA, M., and ORIMOTO, T. 1990. Thermodynamics of phosphorus for the $\mathrm{CaO}-\mathrm{FetO}-\mathrm{CaF}_{2}-\mathrm{SiO}_{2}$ and $\mathrm{CaO}-\mathrm{Al}_{2} \mathrm{O}_{3}$ systems. Tetsu-to Hagane, vol. 76, no. 10. pp. 1664-1671.

Wei, E. YAng, Y., and Sommerville, I.D. 2002. The fundamentals of using custom-designed slags to remove impurities from liquid steel. Proceedings of the 60th Electric Furnace Conference, San Antonio, TX, 10-13 November 2002. Kanagy, D.L. and Baker, M.A. (eds.). Iron \& Steel Society, Warrendale, PA. pp. 761-771.

Zhou, J. Bi , X, HuAng, Z., and Jin, Y. 2011. Phosphorus distribution equilibrium between $\mathrm{CaO}-\mathrm{FeO}^{*}-\mathrm{SiO}_{2}-\mathrm{P}_{2} \mathrm{O}_{5}(15 \%)-\mathrm{CaF}_{2}\left(\mathrm{~B}_{2} \mathrm{O}_{3}\right)$ slag system and carbonsaturated hot metal at $1573 \mathrm{~K}$. Proceedings of the International conference on Chemical, Material and Metallurgical Engineering, Beihai, China 23-25 December, 2011. Trans Tech Publications, Zurich. pp. 369-372. 